\title{
NADPH oxidase-mediated redox signal contributes to lipoteichoic acid-induced MMP-9 upregulation in brain astrocytes
}

\author{
Hsi-Lung Hsieh ${ }^{1 \dagger}$, Chih-Chung Lin ${ }^{2 \dagger}$, Ruey-Horng Shih ${ }^{3}$, Li-Der Hsiao ${ }^{3}$ and Chuen-Mao Yang ${ }^{3,4^{*}}$
}

\begin{abstract}
Background: Lipoteichoic acid (LTA) is a component of gram-positive bacterial cell walls and may be elevated in the cerebrospinal fluid of patients suffering from meningitis. Among matrix metalloproteinases (MMPs), MMP-9 has been observed in patients with brain inflammatory diseases and may contribute to the pathology of brain diseases. Moreover, several studies have suggested that increased oxidative stress is implicated in the pathogenesis of brain inflammation and injury. However, the molecular mechanisms underlying LTA-induced redox signal and MMP-9 expression in brain astrocytes remain unclear.
\end{abstract}

Objective: Herein we explored whether LTA-induced MMP-9 expression was mediated through redox signals in rat brain astrocytes (RBA-1 cells).

Methods: Upregulation of MMP-9 by LTA was evaluated by zymographic and RT-PCR analyses. Next, the MMP-9 regulatory pathways were investigated by pretreatment with pharmacological inhibitors or transfection with small interfering RNAs (siRNAs), Western blotting, and chromatin immunoprecipitation (ChIP)-PCR and promoter activity reporter assays. Moreover, we determined the cell functional changes by migration assay.

Results: These results showed that LTA induced MMP-9 expression via a PKC(a)-dependent pathway. We further demonstrated that PKCa stimulated p47 phox/NADPH oxidase 2 (Nox2)-dependent reactive oxygen species (ROS) generation and then activated the ATF2/AP-1 signals. The activated-ATF2 bound to the AP-1-binding site of MMP-9 promoter, and thereby turned on MMP-9 gene transcription. Additionally, the co-activator p300 also contributed to these responses. Functionally, LTA-induced MMP-9 expression enhanced astrocytic migration.

Conclusion: These results demonstrated that in RBA-1 cells, activation of ATF2/AP-1 by the PKC(a)-mediated Nox (2)/ROS signals is essential for upregulation of MMP-9 and cell migration enhanced by LTA.

\section{Background}

Matrix metalloproteinases (MMPs) comprise a family of calcium- and zinc-dependent proteinases, and are involved in normal development and wound healing as well as in pathological conditions such as atherosclerosis and metastasis. In brain, MMP-9 has been shown to be upregulated during various CNS diseases $[1,2]$. Previous

\footnotetext{
* Correspondence: chuenmao@mail.cgu.edu.tw

${ }^{\dagger}$ Equal contributors

${ }^{3}$ Department of Pharmacology and Health Aging Research Center, College of Medicine, Chang Gung University, Tao-Yuan, Taiwan

${ }^{4}$ Department of Pharmacology, College of Medicine, Chang Gung University, 259 Wen-Hwa 1st Road, Kwei-San, Tao-Yuan, Taiwan

Full list of author information is available at the end of the article
}

reports have indicated that a series of functional element-binding sites have been identified, including NF- $\mathrm{KB}$, Ets and AP-1 within the MMP-9 promoter [3], which can be regulated by diverse stimuli. Moreover, proinflammatory factors including cytokines, endotoxins and oxidative stress have been reported to upregulate MMP9 in astrocytes in vitro [4-6], implying that MMP-9 activity may be regulated by diverse factors in the CNS during neuroinflammation.

It is worth noting that bacterial infections have been found to trigger brain inflammatory diseases [7]. Grampositive bacterial infections of the CNS occur in bacterial meningitis and brain abscess, being localized to the membranes surrounding the brain or in its parenchyma, 
respectively [8]. In the CNS, the glial cells such as astrocytes and microglia are regarded as targets in grampositive bacterial infection $[9,10]$. Lipoteichoic acid (LTA) is a major component of gram-positive bacterial cell walls that induces glial inflammatory activation in vitro and in vivo [11], mediated through TLR2 signaling [12]. In astrocytes, TLR signaling has been shown to be involved in brain inflammatory responses [13], accompanied by upregulation of several genes with proinflammatory and proapoptotic capabilities [14]. However, the role of MMP9 in astrocytes, the major regulator of fundamental biological functions of the CNS [15], in LTA-induced brain inflammation remains poorly defined.

TLR2 is believed to be responsible for LTA recognition challenged by gram-positive bacteria such as Staphylococcus aureus and Streptococcus pneumouniae [16]. Upon binding to TLR heterodimers (i.e., TLR2/ TLR1 or TLR2/TLR6 complex), LTA exerts a sequential activation of members of IL-1 receptor-associated kinase (IRAK) family and tumor necrosis factor receptorassociated factor 6 (TRAF6), mediated by a TLR adaptor protein, MyD88. Ultimately, TLR signaling activates the MAPK family, NF- $\mathrm{kB}$ and AP-1, leading to expression of cytokines and other proinflammatory proteins $[7,8]$. Our previous studies have demonstrated that interleukin-1 (IL-1 $\beta$ ), bradykinin (BK) and oxidized low-density lipoprotein (oxLDL) upregulate MMP-9 expression via NF-kB, Elk-1 and AP-1 signaling in rat astrocytes $[4,17,18]$. In response to pathogenic ligands, TLR2/ MyD88 activates PI3K/Akt, MAPKs and NF-kB pathways, which modulate immune responses following ligand recognition [16,19]. Moreover, activation of these signaling cascades and transcription factors has been reported to be involved in induction of MMP-9 in rat astrocytes $[4,17,18]$. A recent report has shown that LTA increases MMP-9 expression via the ERK pathway in RAW 264.7 macrophages [20]. However, the mechanisms underlying the regulation of MMP-9 expression by LTA in astrocytes are still unclear.

Reactive oxygen species (ROS) are produced by various enzymatic reactions such as NADPH oxidase (Nox). ROS are essential for many physiological functions and killing invading microorganisms [21,22]. Under pathological conditions, increasing ROS production by external stimuli can regulate the expression of several inflammatory genes during brain injury [23-25]. Recently, increasing evidence has attributed the cellular damage in neurodegenerative disorders such as AD to oxidative stress, which leads to the generation of free radicals, which are responsible for brain inflammatory disorders [24,25]. Although the effects of LTA on ROS generation have been reported in tracheal smooth muscle cells and renal diseases [26,27], LTAinduced astrocytic responses through the ROS signal are not well characterized.
Here we investigate the molecular mechanisms underlying LTA-induced MMP-9 expression in cultured RBA1 cells. These findings demonstrate that in RBA- 1 cells, LTA-induced MMP-9 expression is mediated through PKC $\alpha$ and Nox2-dependent generation of the ROS signaling pathway, and ATF2/AP-1. Moreover, upregulation of MMP-9 expression is positively associated with cell migration in these cells.

\section{Methods}

\section{Materials}

DMEM/F-12 medium, FBS, TRIzol and siRNAs of PKC $\alpha, \mathrm{p}_{4} 7^{\text {phox }}$, Nox1, Nox2, Nox4, ATF2 and p300 were from Invitrogen (Carlsbad, CA). Hybond $\mathrm{C}$ membrane and the ECL Western blotting detection system were from GE Healthcare Biosciences (Buckinghamshire, UK). MMP-9 antibody was from NeoMarker (Fremont, CA). PKC $\alpha$ and phospho-ATF2 antibodies were from Cell Signaling (Danver, MA). p47 ${ }^{\text {phox }}$, Nox2 and phospho-p300 antibodies were from Santa Cruz (Santa Cruz, CA). GAPDH antibody was from Biogenesis (Boumemouth, UK). GF109203X, Gö6976, apocynin, diphenylene iodonium (DPI), tanshinone IIA (TSIIA) and GR343 were from Biomol (Plymouth Meeting, PA). Bicinchoninic acid (BCA) protein assay reagent was from Pierce (Rockford, IL). LTA (from Staphylococcus aureus), N-acetyl cysteine (NAC), enzymes and other chemicals were from Sigma (St. Louis, MO).

\section{Cell cultures}

The rat brain astrocytic cell line (RBA-1) originated from a primary astrocyte culture of neonatal rat cerebrum, and was naturally developed through successive cell passages [28] and used throughout this study. Primary astrocyte cultures were prepared from the cortex of 6-day-old Sprague-Dawley rat pups [29]. Rats were maintained according to the Guidelines of the Animal Care Committee of Chang Gung University and the National Institutes of Health Guide for the Care and Use of Laboratory Animals. The purity of primary astrocyte cultures was assessed using an astrocyte-specific marker, GFAP, showing over 95\% GFAP-positive astrocytes. Cells were plated onto 12-well culture plates and made quiescent at confluence by incubation in serum-free DMEM/ F-12 for $24 \mathrm{~h}$. Growth-arrested cells were incubated with LTA at $37^{\circ} \mathrm{C}$ for the indicated time intervals. When the inhibitors were used, cells were pretreated with the inhibitor for $1 \mathrm{~h}$ before exposure to LTA.

\section{MMP gelatin zymography}

Growth-arrested cells were incubated with LTA for the indicated time intervals. Treatment of RBA-1 cells with pharmacological inhibitors or LTA alone had no significant effect on cell viability determined by an XTT assay 
(data not shown). The cultured media were analyzed by gelatin zymography [29]. Gelatinolytic activity was manifested as horizontal white bands on a blue background. Because cleaved MMPs were not reliably detectable, only pro-form zymogens were quantified.

\section{Total RNA extraction and reverse transcription PCR analysis}

Total RNA was extracted from RBA-1 cells [29]. The cDNA obtained from $0.5 \mu \mathrm{g}$ total RNA was used as a template for PCR amplification. Oligonucleotide primers were designed based on Genbank entries for rat MMP-9, Nox1-4 [30] and $\beta$-actin. The following primers were used for amplification reaction: MMP-9, 5'-AGTTTGGTGTCGCGGAGCAC-3' (sense), 5' -TACATGAGCGCTTCCGGCAC-3' (antisense); Nox1， 5'-TACGAAGTGGCTGTACTGGTTG-3' (sense), 5' -CTCCCAAAGGAGGTTTTCTGTT-3' (antisense); Nox2, 5' -TCAAGTGTCCCCAGGTATCC-3' (sense), 5' CTTCACTGGCTGTACCAAAGG-3' (antisense); Nox3, 5' -AATCACAGAGTCTGCCTGGACT-3' (sense), 5' -ATCCAGACTTTCATCCCAGTGT-3' (antisense); Nox4, 5'GGAAGTCCATTTGAGGAGTCAC-3' (sense), 5' TGGATGTTCACAAAGTCAGGTC-3' (antisense); $\beta$-actin, 5'-GAACCCTAAGGCCAACCGTG-3' (sense) and 5'TGGCATAGAGGTCTTTACGG-3' (antisense). The amplification was performed in 30 cycles at $55^{\circ} \mathrm{C}, 30 \mathrm{~s} ; 72^{\circ} \mathrm{C}, 1$ min; $94^{\circ} \mathrm{C}, 30 \mathrm{~s}$. PCR fragments were analyzed on $2 \%$ agarose in $1 \mathrm{X}$ TAE gel containing ethidium bromide, and their size was compared to molecular weight markers. Amplification of $\beta$-actin, a relatively invariant internal reference RNA, was performed in parallel, and cDNA amounts were standardized to equivalent $\beta$-actin mRNA levels. These primer sets specifically recognize only the genes of interest as indicated by amplification of a single band of the expected size (754 bp for MMP-9, 337 bp for Nox1, 209 bp for Nox2, 214 bp for Nox3, 244 bp for Nox4 and 514 bp for $\beta$-actin) and direct sequence analysis of the PCR product. Real-time PCR was performed with the TaqMan gene expression assay system, using primers and probe mixes for MMP-9 and endogenous GAPDH control genes. PCRs were performed using the 7500 Real-Time PCR System (Applied Biosystems, Foster City, CA). The primers were: $5^{\prime}$-(TGATGCCATTGCTGATATCCA)-3' (sense), 5' -(CGGATCCTCAAAGGCTGAGT)-3' (anti-sense) for MMP-9; 5' (AACTTTGGCATCGTGGAAGG)-3' (sense), 5' (GTGGATGCAGGGATGATGTTC)-3' (anti-sense) for GAPDH. Relative gene expression was determined by the $\Delta \Delta C$ t method, where $C t$ meant threshold cycle. All experiments were performed in triplicate $(n=3)$.

\section{Preparation of cell extracts and western blotting analysis} Growth-arrested cells were incubated with LTA for the indicated time intervals. The cell lysates were collected and the protein concentration was determined by the
BCA reagents. Samples from these cell lysates $(30 \mu \mathrm{g}$ protein) were denatured and subjected to SDS-PAGE using a $10 \%(\mathrm{w} / \mathrm{v})$ running gel. The phosphorylation of serine, ATF2, and p300 or total Nox, p47 $7^{\text {phox }}$ PKC $\alpha$, ATF2 and p300 were identified and quantified by Western blotting as previously described [29]. The immunoreactive bands were detected by the UVP Biospectrum ${ }^{\circledR}$ imaging system (Upland, CA).

\section{Measurement of intracellular ROS generation}

The peroxide-sensitive fluorescent probe $2^{\prime}, 7^{\prime}$-dichlorofluorescein diacetate (DCF-DA) was used to assess the generation of intracellular ROS [31] with minor modifications. RBA-1 cells in monolayers were incubated with RPMI-1640 supplemented with $5 \mu \mathrm{M}$ DCF-DA for 45 min at $37^{\circ} \mathrm{C}$. The supernatant was replaced with fresh RPMI-1640 medium before stimulation with LTA (50 $\mu \mathrm{g} / \mathrm{ml})$. Relative fluorescence intensity was recorded over time (0-60 min) by using a fluorescent plate reader (Thermo, Appliskan) at an excitation wavelength of 485 $\mathrm{nm}$, and emission was measured at a wavelength of 530 $\mathrm{nm}$. Fluorescent images were also obtained by using fluorescence microscopy (ZEISS, Axiovert 200 M). The data presented are generated from three separate assays $(n=3)$.

\section{Determination of NADPH oxidase activity by chemiluminescence assay}

The NADPH oxidase activity in intact cells was assayed by lucigenin chemiluminescence assay as described previously [32] with modifications. After incubation, the cells were gently scraped and centrifuged at $400 \times \mathrm{g}$ for $10 \mathrm{~min}$ at $4^{\circ} \mathrm{C}$. The cell pellet was resuspended in a volume $(35 \mu \mathrm{l} /$ well $)$ of ice-cold RPMI 1640 medium, and the cell suspension was kept on ice. To a final $200 \mu \mathrm{l}$ volume of pre-warmed $\left(37^{\circ} \mathrm{C}\right)$ RPMI 1640 medium containing either NADPH $(1 \mu \mathrm{M})$ or lucigenin $(20 \mu \mathrm{M}), 5 \mu \mathrm{l}$ of cell suspension $\left(2 \times 10^{4}\right.$ cells) was added to initiate the reaction followed by immediate measurement of chemiluminescence in a Appliskan luminometer $\left(\right.$ Thermo $^{\circledR}$ ) in out-of-coincidence mode. Appropriate blanks and controls were established, and chemiluminescence was recorded. Neither NADPH nor NADH enhanced the background chemiluminescence of lucigenin alone (3040 counts $/ \mathrm{min}$ ). Chemiluminescence was continuously measured for $12 \mathrm{~min}$, and the activity of NADPH oxidase was expressed as counts per million cells.

\section{Isolation of cell fraction}

After treatment, cells were harvested, sonicated for $5 \mathrm{~s}$ at output 1.5 with a sonicator (Misonix, Inc., Farmingdale, NY) and centrifuged at 8,000 rpm for $15 \mathrm{~min}$ at $4^{\circ}$ C. The pellet was collected as the nuclear fraction. The supernatant was centrifuged at $14,000 \mathrm{rpm}$ for $60 \mathrm{~min}$ at 
$4^{\circ} \mathrm{C}$ to yield the pellet (membrane fraction) and the supernatant (cytosolic fraction).

\section{Immunofluorescence staining}

Growth-arrested cells were treated with LTA $(50 \mu \mathrm{g} / \mathrm{ml})$, washed twice with ice-cold PBS, fixed with $4 \%$ (w/v) paraformaldehyde in PBS for $30 \mathrm{~min}$ and then permeabilized with $0.3 \%$ Triton X-100 in PBS for $15 \mathrm{~min}$. The staining was performed by incubating with $10 \%$ normal goat serum in PBS for $30 \mathrm{~min}$ followed by incubating with an anti-p4 $7^{\text {phox }}$ polyclonal antibody (1:200 dilution) for $1 \mathrm{~h}$ in PBS with $1 \% \mathrm{BSA}$, washing three times with PBS, incubating for $1 \mathrm{~h}$ with fluorescein isothiocyanate (FITC)-conjugated goat anti-rabbit antibody (1:200 dilution) in PBS with $1 \%$ BSA, washing three times with PBS and finally mounting with aqueous mounting medium. The images were observed under a fluorescence microscope (ZEISS, Axiovert $200 \mathrm{M}$ ). The data presented are generated from three separate assays $(n=3)$.

\section{Transient transfection with siRNAs}

The small interfering RNA (siRNA) duplexes corresponding to rat PKC $\alpha, \mathrm{p} 47^{\text {phox }}$, Nox1-4, ATF2, p300 and scrambled siRNA were from Invitrogen (Invitrogen, Carlsbad, CA). Transient transfection of siRNAs (100 $n M)$ was carried out using Lipofetamine ${ }^{\mathrm{TM}}$ RNAiMAX reagent according to the manufacturer's instructions $(n=3)$.

\section{Plasmid construction, transient transfection and promoter activity assay}

The upstream region $(-1280$ to +19$)$ of the rat MMP-9 promoter was cloned to the pGL3-basic vector containing the luciferase reporter system. Briefly, a $1.3-\mathrm{kb}$ segment at the 5 '-flanking region of the rat MMP-9 gene was amplified by PCR using specific primers from the rat MMP-9 gene (accession no. U36476): 5 ' -ccccggtaccGAAGGCGAAATGCTTTGCCC (forward/Kpn1) and 5' -cccctcgaGGGTGAGAACCGAAGCTTCTG (reverse/Xho1). The pGL3-Basic vector, containing a polyadenylation signal upstream from the luciferase gene, was used to construct the expression vectors by subcloning PCR-amplified DNA of the MMP-9 promoter into the Kpn1/Xho1 site of this vector. The PCR products (pGL3-MMP-9WT) were confirmed by their size, as determined by electrophoresis, and by DNA sequencing. All plasmids were prepared by using QIAGEN plasmid DNA preparation kits. The MMP-9-luc constructs were transfected into RBA-1 cells, respectively, using a Lipofectamine reagent according to the manufacturer's instructions. The transfection efficiency ( 60\%) was determined by transfection with enhanced GFP. After incubation with LTA $(50 \mathrm{ng} / \mathrm{ml})$, cells were collected and disrupted by sonication in lysis buffer ( $25 \mathrm{mM}$ Tris, $\mathrm{pH}$
7.8, 2 mM EDTA, 1\% Triton X-100 and 10\% glycerol). After centrifugation, aliquots of the supernatants were tested for luciferase activity using the luciferase assay system. Firefly luciferase activities were standardized for $\beta$-galactosidase activity. The data presented are generated from three separate assays $(n=3)$.

\section{Chromatin immunoprecipitation assay}

To detect the in vivo association of nuclear proteins with rat $m m p-9$ promoter, chromatin immunoprecipitation (ChIP) analysis was conducted as described previously [17]. RBA-1 cells in 100-mm dishes were grown to confluence and serum starved for $24 \mathrm{~h}$. After treatment with LTA, protein-DNA complexes were fixed by $1 \%$ formaldehyde in PBS. The fixed cells were washed and lysed in SDS-lysis buffer (1\% SDS, $5 \mathrm{mM}$ EDTA, $1 \mathrm{mM}$ PMSF, $50 \mathrm{mM}$ Tris- $\mathrm{HCl}, \mathrm{pH} 8.1$ ) and sonicated on ice until the DNA size became 200-1,000 base pairs. The samples were centrifuged, and the soluble chromatin was precleared by incubation with sheared salmon sperm DNAprotein agarose A slurry (Upstate) for $30 \mathrm{~min}$ at $4^{\circ} \mathrm{C}$ with rotation. After centrifugation at $800 \mathrm{rpm}$ for $1 \mathrm{~min}$, one portion of the pre-cleared supernatant was used as DNA input control, and the remains were subdivided into aliquots and then incubated with a non-immune rabbit immunoglobulin G (IgG; Santa Cruz), anti-ATF2 (Santa Cruz), respectively, for overnight at $4^{\circ} \mathrm{C}$. The immunoprecipitated complexes of Ab-protein-DNA were collected by using the above protein A beads and washed successively with low-salt buffer (0.1\% SDS, $1 \%$ Triton X-100, 2 mM EDTA, 20 mM Tris-HCl, pH 8.1, $150 \mathrm{mM} \mathrm{NaCl}$ ), high-salt buffer (same as the low-salt buffer but with $500 \mathrm{mM} \mathrm{NaCl}), \mathrm{LiCl}$ buffer $(0.25 \mathrm{M} \mathrm{LiCl}$, 1\% NP-40, 1\% deoxycholate, 1 mM EDTA, 10 mM Tris$\mathrm{HCl}, \mathrm{pH} \mathrm{8.1)}$ and Tris-EDTA ( $\mathrm{pH} 8.0)$, and then eluted with elution buffer (1\% SDS, $100 \mathrm{mM} \mathrm{NaHCO}$ ). The cross-linking of protein-DNA complexes was reversed by incubation with $5 \mathrm{M} \mathrm{NaCl}$ at $65^{\circ} \mathrm{C}$ for $4 \mathrm{~h}$, and DNA was digested with $10 \mu \mathrm{g}$ of proteinase $\mathrm{K}$ (Sigma)/ml for $1 \mathrm{~h}$ at $45^{\circ} \mathrm{C}$. The DNA was then extracted with phenolchloroform, and the purified DNA pellet was precipitated with isopropanol. After washing, the DNA pellet was resuspended in $\mathrm{H}_{2} \mathrm{O}$ and subjected to PCR amplification with the forward (5'-AGAGCCTGCTCCCAGAGGGC-3') and reverse (5'-GCCAAGTCAGGCAGGACCCC-3'), which were specifically designed from the distal AP-1 mmp-9 promoter region $(-557$ to -247$)$. PCR products were analyzed on ethidium bromide-stained agarose gels $(n=3)$.

\section{Migration assay}

RBA-1 cells were cultured to confluence in 10-cm dishes and starved with serum-free DMEM/F-12 medium for $24 \mathrm{~h}$. The monolayer cells were scratched manually with a blade to create extended and definite scratches in the 
center of the dishes with a bright and clear field. The detached cells were removed by washing the cells once with PBS. Serum-free DMEM/F-12 medium with or without LTA $(50 \mu \mathrm{g} / \mathrm{ml})$ was added to each dish as indicated after pretreatment with the inhibitors for $1 \mathrm{~h}$, containing a DNA synthesis inhibitor hydroxyurea $(10 \mu \mathrm{M})$ in the whole course. Images of migratory cells from the scratch boundary were observed and acquired at 0 and $48 \mathrm{~h}$ with a digital camera and a light microscope (Olympus, Japan). The number of migratory cells was counted from the resulting four phase images for each point and then averaged for each experimental condition. The data presented are generated from three separate assays.

\section{Statistical analysis of data}

Data were estimated using a GraphPad Prism Program (GraphPad, San Diego, CA, USA). Quantitative data were analyzed using ANOVA followed by Tukey's honestly significant difference tests between individual groups. Data were expressed as mean \pm SEM of three independent experiments $(n=3)$. A value of $P<0.05$ was considered significant.

\section{Results}

ROS signal is essential for LTA-induced MMP-9 expression in RBA-1 cells

ROS have been shown to induce MMPs expression in various cell types [33]. To determine whether ROS participated in MMP-9 induction, pretreatment of RBA-1 cells with $\mathrm{N}$-acetylcysteine (NAC, a ROS scavenger, 10 $\mathrm{mM}$ ) attenuated the LTA-induced MMP-9 protein and mRNA expression (Figure 1a and $\mathrm{b}$ ), suggesting that ROS may play a crucial role in LTA-induced MMP-9 expression in RBA-1 cells. To determine whether LTA stimulates intracellular ROS generation, as shown in Figure 1c, LTA stimulated ROS generation in a timedependent manner that was markedly attenuated by pretreatment with NAC, indicating that LTA stimulated ROS generation. To demonstrate whether LTA-induced MMP-9 expression via the ROS-dependent pathway also occurred in primary cultured astrocytes, as shown in Figure 1d, pretreatment with NAC concentrationdependently inhibited LTA-induced MMP-9 expression in primary cultured astrocytes. To demonstrate the functional activity of MMP-9 induced by LTA, we evaluated cell migration of primary culture astrocytes. The images of cell migration were taken and counted at $48 \mathrm{~h}$ induction by LTA $(50 \mu \mathrm{g} / \mathrm{ml})$. As shown in Figure 1d (lower panel), LTA-induced cell migration was significantly blocked by pretreatment with the inhibitors of MMP2/9 $(2 / 9 \mathrm{i}, 1 \mu \mathrm{M})$ or ROS $(\mathrm{NAC}, 10 \mathrm{mM})$. These data suggested that upregulation of MMP-9 and its activity via the ROS-dependent pathway is required for enhancing cell migration induced by LTA in brain astrocytes. Taken together, these results demonstrated that LTA-induced responses in rat primary cultured astrocytes are similar to those of RBA-1 cells. Thus, the following experiments were performed using RBA-1 cells, which can be applied as a model throughout this study.

\section{Nox2-derived ROS generation is involved in LTA-induced MMP-9 expression}

NADPH oxidase (Nox) is considered to be a major source of ROS in several physiological and pathological processes [21,34]. To further explore whether LTAinduced MMP-9 expression mediated through activation of Nox activation, as shown in Figure 2a and b, pretreatment with a Nox activity inhibitor diphenyleneiodonium (DPI, $1 \mu \mathrm{M}$ ) or $447^{\text {phox }}$ inhibitor apocynin (Apo, $10 \mu \mathrm{M}$ ) significantly attenuated the LTA-induced MMP-9 protein and mRNA expression in RBA-1 cells. To further demonstrate whether LTA stimulates $\mathrm{p} 47^{\text {phox }}$-mediated Nox activity, as shown in Figure 2c, LTA stimulated Nox activity and ROS generation, which was attenuated by pretreatment with DPI $(1 \mu \mathrm{M})$ or Apo $(10 \mu \mathrm{M})$, suggesting that $\mathrm{p} 47^{\text {phox }} /$ Nox-derived ROS is involved in LTA-induced MMP-9 expression in RBA-1 cells. To determine which Nox isotypes are involved in these responses, the expression of Nox isotypes was analyzed, and transfection with Nox siRNA was performed. First, we found that Nox1, Nox2 and Nox4 were expressed in RBA-1 cells and Nox2 was predominantly expressed in comparison to the other two determined by RT-PCR (data not shown). Next, transfection with Nox2 siRNA knocked down the expression of Nox 2 protein and significantly attenuated LTA-induced MMP-9 expression in RBA-1 cells (Figure 2d). These results suggested that LTA-induced MMP-9 expression is mediated through Nox2-dependent ROS generation in these cells.

\section{Involvement of $\mathrm{p} 47^{\text {phox }}$ in LTA-induced MMP-9 expression} Moreover, phosphorylation and translocation of $\mathrm{p} 47^{\text {phox }}$ to plasma membrane are important events in the activation of Nox [35,36]. Therefore, we first determined whether LTA stimulates $\mathrm{p} 47^{\text {phox }}$ phosphorylation at serine residues; as shown in Figure 3a, LTA stimulated $\mathrm{p} 47^{\text {phox }}$ serine phosphorylation in a time-dependent manner, which was attenuated by pretreatment with Apo $(10 \mu \mathrm{M})$. We next determined the effect of LTA on translocation of $\mathrm{p} 47^{\text {phox }}$; cells were treated with LTA for $10 \mathrm{~min}$ in the absence or presence of Apo. The membrane fraction was analyzed by Western blot using an anti-phospho-serine (p-Ser) or anti-p47 $7^{\text {phox }}$ antibody. LTA stimulated a significant translocation of $\mathrm{p} 47^{\text {phox }}$ from the cytosol to the membrane with a maximal response within $10 \mathrm{~min}$, which was attenuated by pretreatment with Apo (Figure 3b, left part). The results were 


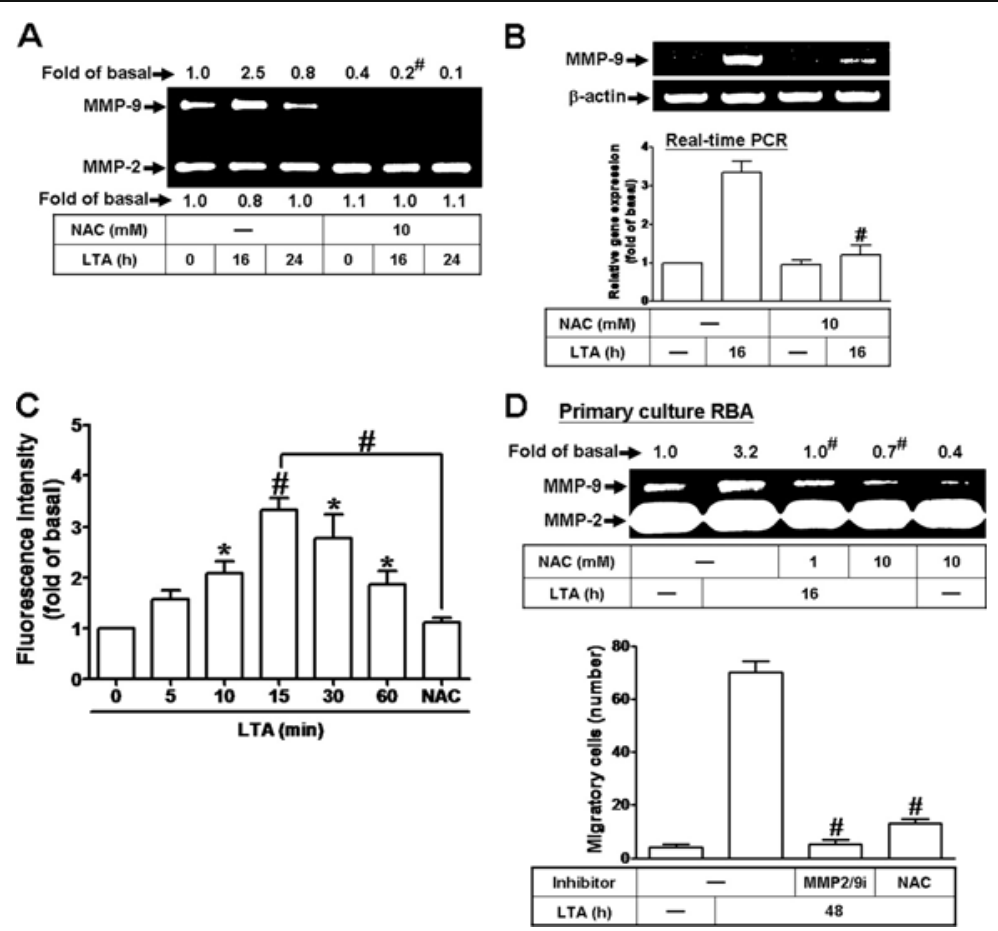

Figure 1 ROS are essential for LTA-induced MMP-9 expression in RBA-1 cells. a Cells were pretreated with or without N-acetylcysteine (NAC, $10 \mathrm{mM}$ ) for $1 \mathrm{~h}$ before exposure to $50 \mathrm{\mu g} / \mathrm{ml}$ LTA for the indicated time intervals. The conditioned media were analyzed by gelatin zymography for MMP-9 expression and activity. b Cells were treated with or without NAC (10 mM) for $1 \mathrm{~h}$ before exposure to $50 \mathrm{\mu g} / \mathrm{ml} \mathrm{LTA}$ for $16 \mathrm{~h}$. The total RNA was analyzed by RT-PCR (upper panel) and real-time RT-PCR (lower panel). c Cells were incubated with the peroxide-sensitive fluorescent probe DCF-DA $(5 \mu \mathrm{M})$ for $45 \mathrm{~min}$, followed by stimulation with $50 \mu \mathrm{g} / \mathrm{ml}$ LTA for the indicated time intervals or for $15 \mathrm{~min}$ in presence or absence of $10 \mathrm{mM}$ NAC. The fluorescence intensity of cells was determined. $\mathbf{d}$ Rat primary astrocytes were isolated and cultured, and pretreated with or without NAC (1 or $10 \mathrm{mM}$ ) before exposure to LTA for $16 \mathrm{~h}$. The conditioned media were analyzed by gelatin zymography (upper panel). For cell migration, cells were plated on coverslips and grown to confluence, then the coverslips were transferred to a new $10-\mathrm{cm}$ dish containing serum-free medium for $24 \mathrm{~h}$. Cells were pretreated with MMP2/9 inhibitor (2/9i) or NAC for $1 \mathrm{~h}$ and then incubated with LTA (50 $\mu \mathrm{g} / \mathrm{ml}$ ) for $48 \mathrm{~h}$. Phase contrast images of cells were taken. The number of LTA-induced cell migrations was counted (lower panel). Data are expressed as the mean \pm SEM of three independent experiments. ${ }^{*} P<0.05 ;{ }^{\#} P<0.01$, as compared with the respective values of cells stimulated with vehicle $(\mathbf{c})$ or LTA alone $(\mathbf{c}, \mathbf{d})$. The figure represents one of three similar experiments.

further supported by the data of fluorescence images obtained using fluorescent microscopy (Figure 3b, right part). Moreover, to further demonstrate the role of $\mathrm{p} 47^{\text {phox }}$ in the MMP-9 induction by LTA, as shown in Figure 3c, transfection with $447^{\text {phox }}$ siRNA knocked down the expression of $\mathrm{p} 47^{\text {phox }}$ protein and significantly attenuated LTA-induced MMP-9 expression. These results suggested that $\mathrm{p} 47^{\text {phox }} /$ Nox-dependent ROS generation plays a crucial role in LTA-induced MMP-9 expression in RBA-1 cells.

\section{LTA induces MMP-9 expression via PKCa-dependent pathway}

Several PKC isoforms such as PKC- $\alpha$ have been shown to regulate MMP-9 expression in various cell types [37]. Recent reports also suggested that activation of Nox/ ROS signaling might be mediated through PKC $[36,38]$. Here we further demonstrated which PKC isoforms are involved in LTA-induced Nox/ROS generation and MMP-9 expression. Pretreatment with either a pan-PKC inhibitor GF109203X $(30 \mu \mathrm{M})$ or a selective PKC $\alpha$ inhibitor Gö6976 (1 $\mu \mathrm{M})$ significantly inhibited LTAinduced MMP-9 expression (Figure 4a) as revealed by zymography, suggesting that PKC (PKC- $\alpha$ especially) plays a potential role in LTA-induced MMP-9 expression. LTA also stimulated PKC $\alpha$ translocation from the cytosol to the membrane in a time-dependent manner with a maximal increase within 10-15 min (Figure 4b, upper part), which was attenuated by pretreatment with Gö6976 (1 $\mu \mathrm{M})$ (Figure 4b, lower part), confirming the involvement of PKC $\alpha$ in LTA-induced MMP-9 expression in RBA-1 cells. We further examined the role of $\operatorname{PKC}(\alpha)$ in LTA-stimulated Nox activity and ROS generation; as shown in Figure 4c, LTA-stimulated Nox activation and ROS generation were blocked by pretreatment with GF109203X (GF, $30 \mu \mathrm{M})$ or Gö6976 


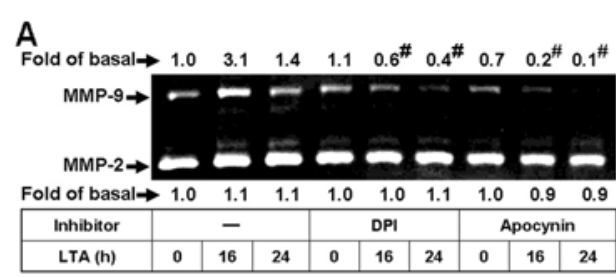

\section{B}
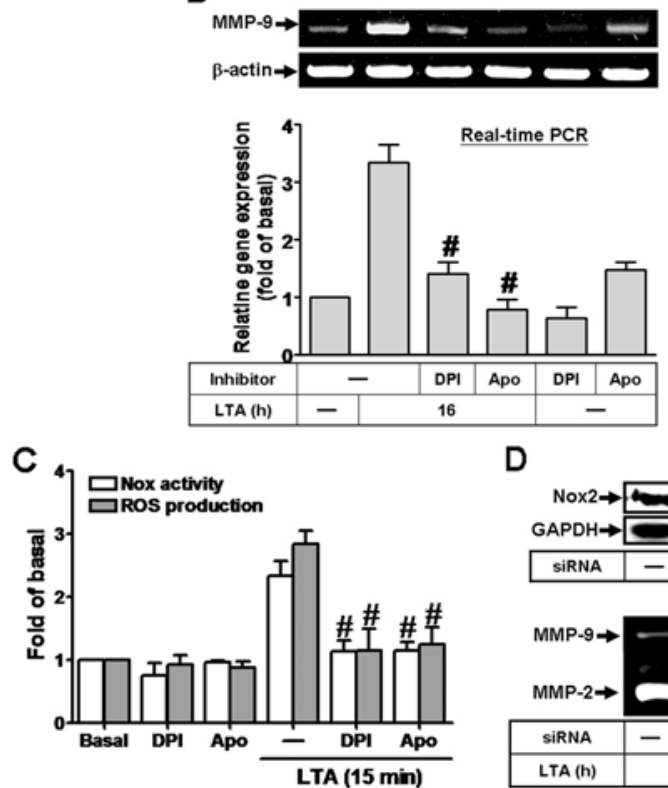

D

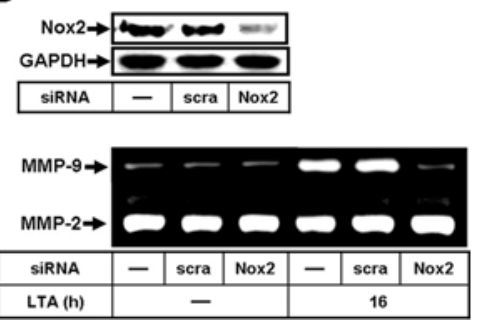

Figure 2 NADPH oxidase (Nox)-dependent ROS generation is involved in LTA-induced MMP-9 expression in RBA-1 cells. a Cells were pretreated with or without DPI $(1 \mu \mathrm{M})$ or apocynin (Apo, $10 \mu \mathrm{M})$ for $1 \mathrm{~h}$ before exposure to LTA $(50 \mu \mathrm{g} / \mathrm{ml})$ for the indicated time intervals. The conditioned media were analyzed by gelatin zymography for MMP-9 expression and activity. $\mathbf{b}$ The total RNA was collected and MMP-9 mRNA expression analyzed by RT-PCR (upper panel) and real-time RT-PCR (lower panel). c Cells were pretreated with or without DPI (1 $\mu \mathrm{M})$ or apocynin (Apo, $10 \mu \mathrm{M}$ ) for $1 \mathrm{~h}$ before exposure to $50 \mu \mathrm{g} / \mathrm{ml}$ LTA for $15 \mathrm{~min}$. The Nox activity and ROS generation were analyzed. d Cells were transfected with scramble (scra) or Nox2 siRNA for $24 \mathrm{~h}$, followed by stimulation with LTA for $16 \mathrm{~h}$. The conditioned media and cell lysates were collected for gelatin zymography or Western blotting analysis of Nox2 and GAPDH (as an internal control). Data are expressed as the mean \pm SEM of three independent experiments. ${ }^{*} P<0.05 ;{ }^{\#} P<0.01$, as compared with the $r$ cells stimulated with LTA (c) alone. The figure represents one of three similar experiments.

(Go, $1 \mu \mathrm{M}$ ). To ensure the phosphorylation of $\mathrm{p} 47^{\mathrm{phox}}$ at serine residues mediated through PKC- $\alpha$, as shown in Figure 4d, LTA-stimulated phosphorylation of serine residues on $\mathrm{p} 47^{\text {phox }}$ was attenuated by pretreatment with Gö6976 $(1 \mu \mathrm{M})$. To confirm the role of PKC $\alpha$ in MMP-9 induction by LTA, as shown in Figure 4e, transfection with PKCa siRNA knocked down the expression of $\mathrm{PKC} \alpha$ protein and significantly attenuated LTA-induced MMP-9 expression. These results demonstrated that PKCo participates in LTA-induced Nox/ROS generation and MMP-9 expression in RBA-1 cells.

\section{ATF-2/AP-1 is required for LTA-induced MMP-9 expression} in RBA-1 cells

Activating transcription factor (ATF) subfamily (ATFa, ATF-1 ATF-2 and ATF-3) is a member of AP-1 transcription factor complex. ATF-2 and Fos proteins are commonly seen in pathological processes. However, the role of ATF-2 in LTA-induced MMP-9 expression is still unknown. Thus, we investigated whether ATF2 is involved in LTA-induced MMP-9 expression in RBA-1 cells; as shown in Figure 5a, transfection with ATF-2 siRNA downregulated ATF-2 protein expression and significantly attenuated LTA-induced MMP-9 expression in RBA-1 cells, suggesting that ATF2/AP-1 is an important factor in LTA-induced MMP-9 expression. To determine whether the phosphorylation of ATF-2 is essential for LTA-induced MMP-9 expression, we found that LTA stimulated phosphorylation of ATF2 in a time-dependent manner. There was a significant increase within $60 \mathrm{~min}$ and reached a maximal response by $90 \mathrm{~min}$ (Figure 5b). Pretreatment with an AP-1 inhibitor TSIIA $(10 \mu \mathrm{M})$ markedly attenuated LTA-stimulated ATF-2 phosphorylation (Figure 5c). To 


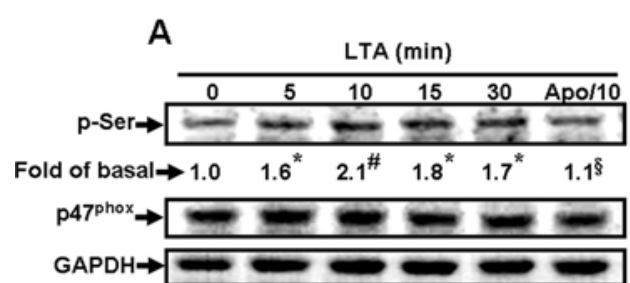

B

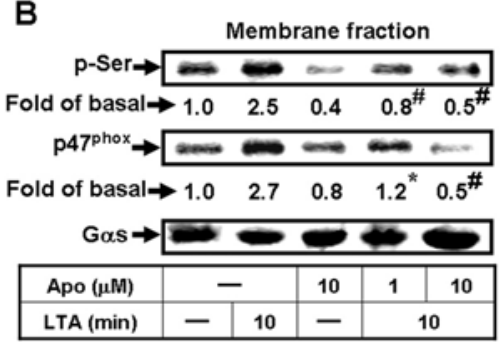

C
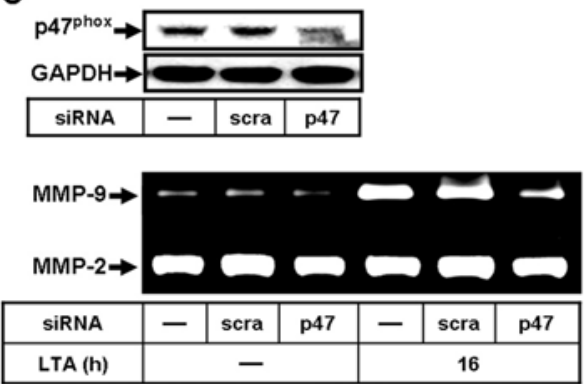

Figure 3 Involvement of $\mathbf{p} 47^{\text {phox }}$ translocation in LTA-induced MMP-9 expression. Cells were pretreated without or with Apo (10 $\mu$ M) for 1 $\mathrm{h}$ and then stimulated with $50 \mathrm{\mu g} / \mathrm{ml}$ LTA for the indicated time intervals or $10 \mathrm{~min}$. a The whole cell lysates and (b) the membrane fraction were prepared and analyzed by Western blotting using an anti-phospho-serine (p-Ser), p47 $7^{\text {phox }}$ or Gas (as a membrane control) antibody. The p47 phox translocation was also observed by immunofluorescent staining. c Cells were transfected with scramble (scra) or p47 ${ }^{\text {phox }}$ siRNA for $24 \mathrm{~h}$, followed by stimulation with LTA for $16 \mathrm{~h}$. The conditioned media and cell lysates were analyzed by gelatin zymography or Western blotting analysis of p47 ${ }^{\text {phox }}$ and GAPDH. Data are expressed as the mean of three independent experiments. ${ }^{*} P<0.05 ;{ }^{\#} P<0.01$, as compared with the cells stimulated with vehicle $(\mathbf{a})$ and $\operatorname{LTA}(\mathbf{a}, \mathbf{b})$ alone. ${ }^{\S} P<0.01$, as compared with the cells stimulated with LTA $(\mathbf{a})$ alone. The figure represents one of three similar experiments.

determine whether PKC and Nox/ROS are involved in LTA-stimulated ATF-2 phosphorylation, as shown in Figure 5c, pretreatment with Gö6976 $(1 \mu \mathrm{M})$, NAC $(10 \mathrm{mM})$, DPI $(1 \mu \mathrm{M})$ or Apo $(10 \mu \mathrm{M})$ attenuated LTA-stimulated ATF-2 phosphorylation, indicating that LTA-stimulated ATF-2/AP-1 phosphorylation was mediated through the $\mathrm{PKC} / \mathrm{Nox} / \mathrm{ROS}$ cascade in RBA-1 cells. Here we also used the ChIP-PCR assay to determine whether ATF2/AP-1 is involved in LTA-induced MMP9 gene expression. We first designed a pair of primers for MMP-9 promoter (-597 to -318), containing an AP-1 binding site. Chromatin was immunoprecipitated using an anti-phospho-ATF-2 antibody, and the MMP9 promoter region ( -597 to -318 ) was amplified by PCR. As shown in Figure 5d, in vivo binding of phosphoATF-2 to the MMP-9 promoter was time-dependently increased by LTA, which was attenuated by NAC (Figure 5d). These results suggested that ROSdependent signaling is involved in LTA-induced ATF-
2/AP-1 binding to the MMP-9 promoter in RBA-1 cells.

\section{The transcriptional co-activator $\mathrm{p} 300$ is crucial for LTA-induced MMP-9 expression}

Several studies have reported that $\mathrm{p} 300$, a transcriptional co-activator, plays a critical role in many gene transcription-regulating events [39]. Hence, we also investigated the role of p300 in LTA-induced MMP-9 expression. Pretreatment with the p300 inhibitor garcinol (GR343, 0.1-10 $\mu \mathrm{M})$ concentration-dependently inhibited LTAinduced MMP-9 expression (Figure 6a). To determine whether the phosphorylation of p300 is essential for LTA-induced MMP-9 expression, we found that LTA stimulated phosphorylation of p300 in a time-dependent manner (Figure 6b). To determine whether PKC and Nox/ROS are involved in LTA-stimulated p300 phosphorylation, as shown in Figure 6c, pretreatment with Gö6976 $(1 \mu \mathrm{M})$, DPI $(1 \mu \mathrm{M})$, NAC $(10 \mathrm{mM})$ or Apo $(10$ 


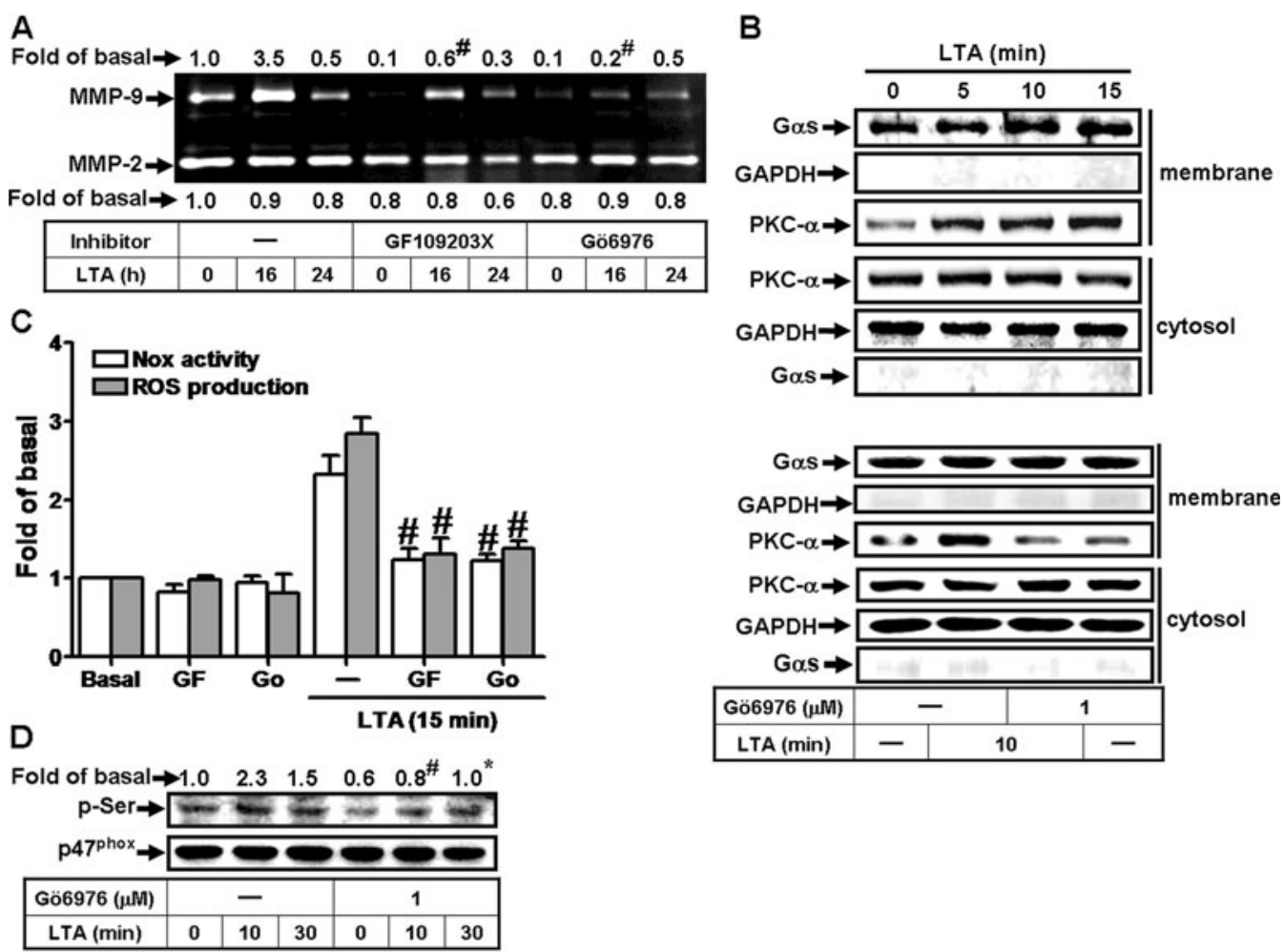

E

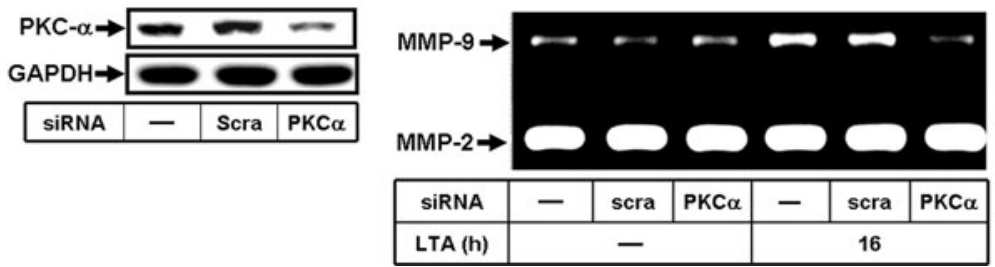

Figure 4 LTA induces ROS generation and MMP-9 expression via PKCa. a Cells were pretreated with or without GF109203X (GF, 30 HM) or Gö6976 (Gö, $1 \mu \mathrm{M}$ ) for $1 \mathrm{~h}$ before exposure to $50 \mu \mathrm{g} / \mathrm{ml}$ LTA for the indicated time intervals. The conditioned media were analyzed by gelatin zymography. b Cells were pretreated without or with Gö $(1 \mu \mathrm{M})$ for $1 \mathrm{~h}$ and then incubated with LTA for the indicated time intervals (upper part) or $10 \mathrm{~min}$ (lower part). The membrane and cytosol fractions were prepared and analyzed by Western blotting using anti-PKC-a, Gas (as a membrane control) or GAPDH antibody. c Cells were pretreated with or without GF or Gö for $1 \mathrm{~h}$ before exposure to LTA for 15 min. The Nox activity and ROS generation were analyzed. $\mathbf{d}$ Cells were pretreated with or without Gö $(1 \mu \mathrm{M})$ for $1 \mathrm{~h}$ before exposure to LTA for the indicated time intervals. e Cells were transfected with scramble (scra) or PKCa siRNA for 24 h, followed by stimulation with LTA for 16 h. The conditioned media and cell lysates were analyzed by gelatin zymography or Western blotting analysis. The cell lysates were analyzed by Western blotting using anti-phospho-serine (p-Ser), p47 ${ }^{\text {phox }}$ or GAPDH antibody. Data are expressed as the mean \pm SEM of three independent experiments. ${ }^{*} P<0.01 ;{ }^{\#} P<0.01$, as compared with the cells stimulated with LTA $(\mathbf{c}, \mathbf{d})$ alone. The figure represents one of three similar experiments.

$\mu \mathrm{M})$ attenuated LTA-stimulated p300 phosphorylation, indicating that LTA-stimulated p300 phosphorylation was mediated through the PKC $\alpha / \mathrm{Nox} / \mathrm{ROS}$ cascade in RBA-1 cells. To confirm the role of p300 in LTAinduced MMP-9 expression, as shown in Figure 6d, transfection with p300 siRNA knocked down the expression of p300 protein and inhibited MMP-9 induction by LTA. These results demonstrated that the PKC $\alpha / \mathrm{Nox} /$ ROS-mediated p300 cascade plays an important role in LTA-induced MMP-9 expression in RBA-1 cells.
LTA induces MMP-9 promoter activity and astrocytic migration

We further investigated whether LTA-stimulated MMP9 transcription activity was also mediated through this ROS-dependent pathway. The MMP-9 promoter was constructed into a pGL3-basic vector containing the luciferase reporter system (pGL-MMP-9-Luc), which contained AP-1 binding sites. LTA-induced MMP-9 promoter activity was attenuated by pretreatment with Gö6976 (Gö, $1 \mu \mathrm{M}$ ), DPI (1 $\mu \mathrm{M})$, apocynin (Apo, 10 


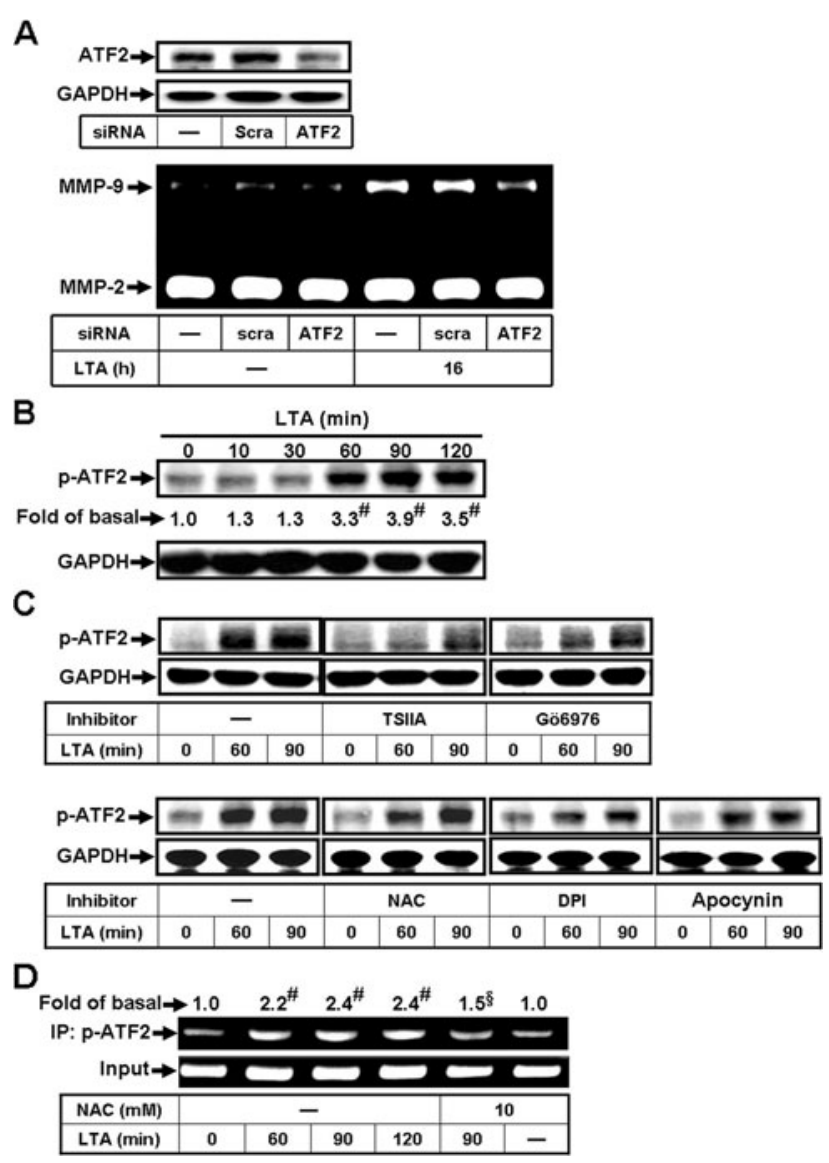

Figure 5 ATF-2/AP-1 is required for LTA-induced MMP-9 expression. a RBA-1 cells were transfected with scramble (scra) or ATF2 siRNA for $24 \mathrm{~h}$, followed by stimulation with $50 \mathrm{\mu g} / \mathrm{ml}$ LTA for $16 \mathrm{~h}$. The conditioned media and cell lysates were analyzed by gelatin zymography or Western blotting. b Cells were treated with LTA for the indicated time intervals. c Cells were pretreated with or without tanshinone IIA (TSIIA, 10

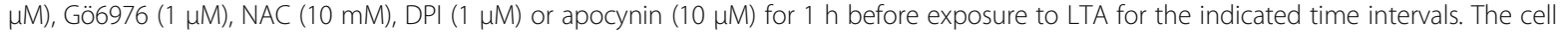
lysates were analyzed by Western blotting using an anti-phospho-ATF-2 (p-ATF2) or GAPDH antibody. d RBA-1 cells were pretreated with NAC $(10 \mathrm{mM})$ for $1 \mathrm{~h}$ and then incubated with LTA $(50 \mu \mathrm{g} / \mathrm{ml})$ for the indicated time intervals or $90 \mathrm{~min}$. The ATF-2/AP-1 binding activity was analyzed by chromatin-IP (ChIP)-PCR assay. Data are expressed as the mean of three independent experiments. ${ }^{\#} P<0.01$, as compared with the cells stimulated with vehicle $(\mathbf{b}, \mathbf{d})$ or ${ }^{\S} P<0.05$, as compared with the cells stimulated with LTA (d) alone. The figure represents one of three similar experiments.

$\mu \mathrm{M})$, NAC (10 mM) or GR343 (10 $\mu \mathrm{M})$ (Figure 7a). To demonstrate the functional activity of MMP-9 induced by LTA, we evaluated cell migration of RBA-1 cells. The images of cell migration were taken and counted at $48 \mathrm{~h}$ induction by LTA $(50 \mu \mathrm{g} / \mathrm{ml})$. As shown in Figure $7 \mathrm{~b}$, LTA-induced cell migration was significantly blocked by pretreatment with the inhibitors of MMP2/9 (2/9i), PKC $\alpha$ (Gö, $1 \mu \mathrm{M})$, Nox (DPI, $1 \mu \mathrm{M})$, ROS (NAC, 10 $\mathrm{mM})$ or p300 (GR, $10 \mu \mathrm{M})$. Taken together, these results suggested that upregulation of MMP-9 and its activity via the PKC $\alpha$-dependent Nox/ROS and p300 pathway is required for enhancing cell migration induced by LTA in RBA-1 cells.

\section{Discussion}

Excessive MMP-9 expression and activity are associated with sustained inflammation and BBB breakdown, leading to brain injury. Blockade of MMP-9 activity by pharmacological inhibitors or gene knockout strategies provide protective effects against cerebral ischemia $[39,40]$. Moreover, the gram-positive bacterium Streptococcus pneumoniae is the most common cause of acute bacterial meningitis worldwide [41,42], revealing a close relationship between LTA challenges and CNS diseases. The pathogenic progression involves glial activation and TLR2 signaling stimulated by LTA, which are linked to inflammatory neurodegeneration [9-11]. Additionally, LTA exhibits detrimental effects on brain cellular functions, including induction of apoptosis, production of oxidative stresses and disruption of BBB following group B Streptococcus or Staphylococcus aureus challenge in the CNS [9-11]. Despite an obviously important role of LTA in brain diseases, the processes by which LTA was implicated in astrocytic functions are not completely 
A

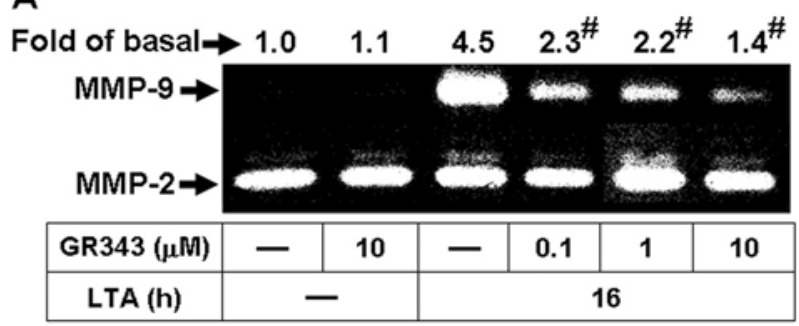

B

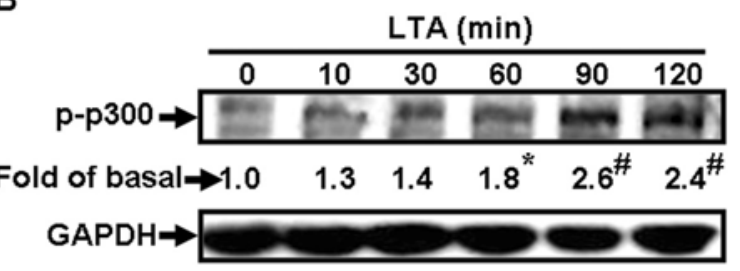

C

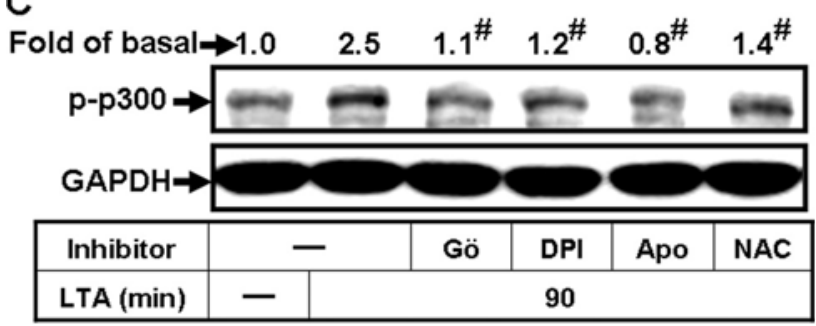

D

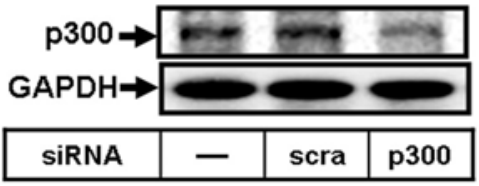

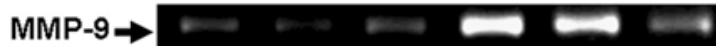
MMP-2 $\rightarrow \longrightarrow \infty C$

\begin{tabular}{|c|c|c|c|c|c|c|}
\hline siRNA & - & scra & p300 & - & scra & p300 \\
\hline LTA (h) & \multicolumn{3}{|c|}{-} & \multicolumn{3}{c|}{16} \\
\hline
\end{tabular}

Figure 6 The transcriptional co-activator p300 contributes to LTA-induced MMP-9 expression. a Cells were pretreated with or without GR343 for $1 \mathrm{~h}$ before exposure to $50 \mathrm{\mu g} / \mathrm{ml}$ LTA for $16 \mathrm{~h}$. The conditioned media were analyzed by gelatin zymography. $\mathbf{b}, \mathbf{c}$ Cells were pretreated without or with Gö6976 (Gö, $1 \mu \mathrm{M})$, DPI (1 $\mu \mathrm{M})$, apocynin $(10 \mu \mathrm{M})$ or NAC $(10 \mathrm{mM})$ for $1 \mathrm{~h}$, and then incubated with $50 \mu \mathrm{g} / \mathrm{ml}$ LTA for the indicated time intervals (b) or 90 min (c). The cell lysates were analyzed by Western blotting using an anti-phospho-p300 (p-p300) or GAPDH antibody. d Cells were transfected with scramble (scra) or p300 siRNA for $24 \mathrm{~h}$, followed by stimulation with $50 \mu \mathrm{g} / \mathrm{ml}$ LTA for $16 \mathrm{~h}$. The conditioned media and cell lysates were collected and analyzed by gelatin zymography or Western blotting. Data are expressed as the mean of three independent experiments. ${ }^{*} P<0.05 ;{ }^{\#} P<0.01$, as compared with the cells stimulated with vehicle $(\mathbf{b})$ or LTA $(\mathbf{a}, \mathbf{c})$ alone. The figure represents one of three similar experiments.

understood. Thus, we investigated the mechanisms underlying LTA-induced MMP-9 expression and its effects. Our recent studies have demonstrated that $\mathrm{c}$ Src-dependent NF- $\mathrm{KB}$ and $\mathrm{Ca}^{2+} / \mathrm{CaMKII-dependent}$ JNK/c-Jun pathways mediate LTA-induced MMP-9 expression and cell migration in RBA-1 cells $[43,44]$. Here, we further demonstrated that a $\mathrm{PKC \alpha} / \mathrm{Nox} 2 / \mathrm{ROS}$ - dependent ATF2/AP-1 and p300 pathway is also involved in LTA-induced MMP-9 expression and cell migration in brain astrocytes (Figure 7b). Based on these findings, Figure 7c depicts a model for the PKC $\alpha$ mediated activation of $\mathrm{p} 47^{\text {phox }} /$ Nox2/ROS-dependent ATF2/AP-1 and p300 signaling pathway implicated in LTA-induced MMP-9 expression and cell migration in 
RBA-1 cells. On the basis of these results and our previous studies, we suggested that LTA-induced MMP-9 expression may be mediated through diverse signaling molecules and pathways, which make joint efforts to enhance MMP-9 gene expression and cell migration in brain astrocytes. However, we will further investigate the relationship among these different pathways associated with MMP-9 expression in the future.

The ROS may exert a key role in the normal physiological functions and the inflammatory responses $[22,45]$. Several lines of evidence have indicated that ROS play a causative role in numerous disease pathologies such as ischemia/reperfusion injury and degenerative diseases such as atherosclerosis, arthritis and neurodegeneration $[24,25]$. In the brain, the role of ROS extends to the control of vascular tone, which is tightly modulated by metabolic activity within neurons $[21,23]$. Increasing evidence also attributes the cellular damage in neurodegenerative disorders such as $\mathrm{AD}$ to oxidative stress that is due to the generation of free radicals implicated in brain inflammatory disorders $[24,25,45]$. The effects of LTA on ROS generation have been reported in human renal [27] and tracheal diseases [26]. In this study, we found and confirmed that LTA-induced MMP9 expression is mediated through Nox-dependent ROS generation in RBA-1 cells (Figure 1). Consistently, many reports have also shown that ROS are a major signaling factor that mediates microglial activation induced by inflammatory mediators, including LPS [46]. Herein we are the first group to establish that Nox-dependent ROS generation contributes to upregulation of MMP-9 induced by LTA in brain astrocytes.

The Nox is considered to be a major source of ROS in several physiological and pathological processes $[21,35]$. To date, five Nox isotypes have been discovered, including Nox1-5 [34]. Several reports have shown that Nox1, Nox2 and Nox4 are expressed in brain cells [21,34], suggesting that these Nox isotypes may be essential for ROS generation. However, the role of these enzymes in the upregulation of brain astrocytic MMP-9 is still unclear. Our data demonstrated that Nox activity is involved in these responses by pretreatment with a Nox inhibitor DPI (Figures 2a-c). Moreover, we also found that Nox1, Nox2 and Nox4 are expressed in RBA-1 cells by RT-PCR (data not shown). The data of knockdown distinct Nox by transfection with their respective siRNA indicated that LTAinduced MMP-9 expression was mediated through activation of Nox2 in RBA-1 cells (Figure 2d). The data further showed that phosphorylation and translocation of the $\mathrm{p} 47^{\text {phox }}$ subunit, a component of Nox2, is crucial for LTAinduced these responses (Figure 3). These results are consistent with previous studies showing that Nox is expressed in astrocytes, contributes to ROS generation $[47,48]$ and leads to LPS-induced MMPs expression in
Raw264.7 cells [49]. We also suggested that the LTAstimulated $\mathrm{p} 47^{\text {phox }}$-dependent Nox $2 /$ ROS signal and MMP9 expression might be mediated through PKC $\alpha$ in RBA-1 cells (Figure 4). It is consistent with the report indicating that PKC $\alpha$ can phosphorylate $\mathrm{p} 47^{\text {phox }}$, and induce both its translocation and then Nox activation in human neutrophils [36].

The excessive increase of oxidative stress during injuries can modulate the pattern of gene expression through various transcription factors. Here we focus on the roles of transcription factor AP-1, which is well known to be modulated during oxidative stress associated with inflammatory diseases [50]. Accumulating evidence has shown that MMP-9 is upregulated via an AP-1dependent manner in various cell types [5,18]. Upon stimulation, ATF-2 is known to form heterodimers with Jun family transcription factors and bind to a specific AP-1 site in the promoter region of target genes, and enhances the gene transcription [51]. Our data showed that ATF-2 phosphorylation is essential for LTA-induced MMP-9 expression, determined by AP-1 inhibitor (TSIIA) (Figure 5). Such inhibitory effects were also confirmed by transfection with ATF-2 siRNA on MMP-9 expression (Figure 5a). Theses results are consistent with the mechanisms of MMP-2 expression in human breast epithelial cells [52]. Moreover, AP-1 binding sites have been identified in the MMP-9 gene promoter [3], which might explain the modulation exerted by LTA. Our data further showed that LTA enhanced phospho-ATF-2 binding to MMP-9 promoter, determined by a ChIPPCR assay (Figure $5 \mathrm{~d}$ ), consistent with the responses of phosphorylation of ATF-2 (Figure 5b). These results suggested that LTA stimulated ATF-2/AP-1 phosphorylation and binding activity via a ROS-dependent pathway, consistent with ROS-dependent activation of ATF-2 being involved in $\mathrm{H} 9 \mathrm{c} 2$ cells [53].

Moreover, the transcription co-activator p300 is vital for the co-activation of several transcription factors such as AP-1 in the transcription machinery, which has a significant role in the activation of AP-1-mediated gene expression for proinflammatory mediators [39]. Our results indicated that p300 plays an important role in LTA-induced MMP-9 expression (Figure 6a). Moreover, we found that LTA increased phosphorylation of p300 is also mediated through a $\mathrm{PKC}(\alpha) / \operatorname{Nox}(2) / \operatorname{ROS}$ cascade (Figures $1 \mathrm{~b}$ and $\mathrm{c}$ ). The result of p300 siRNA transfection further confirmed that p300 may contribute to enhance transcriptional activation of MMP-9 by LTA (Figure 6d). It was consistent with previous studies indicating p300-dependent MMP-9 expression by BK or IL$1 \beta$ in astrocytes $[17,54]$ and a recent study showing that ROS-dependent p300 activation leads to $\mathrm{CPLA}_{2}$ expression by cigarette smoke extract in human tracheal smooth muscle cells [55]. Subsequently, we also 
A

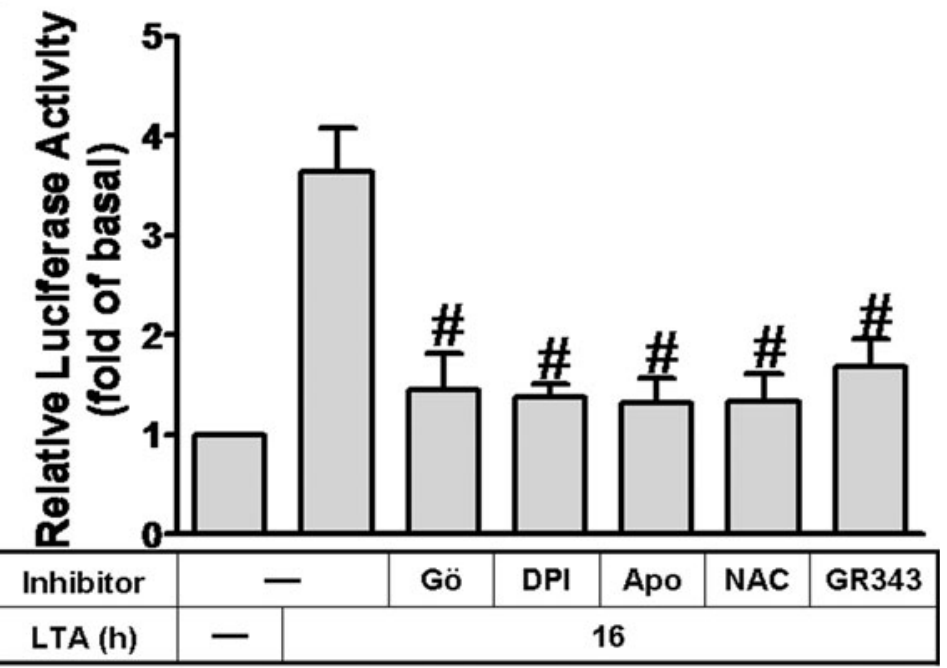

B

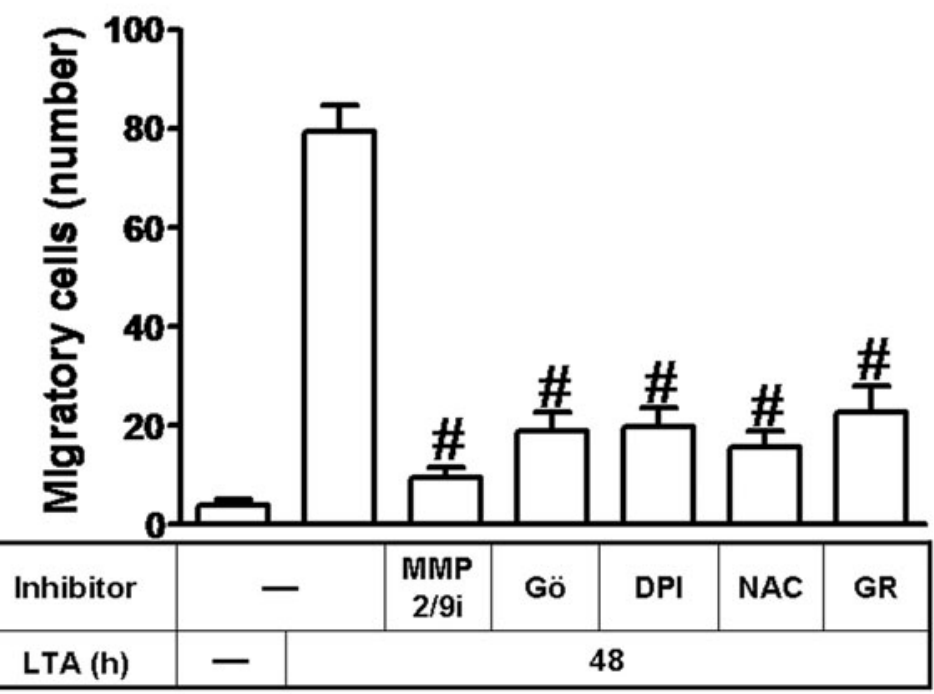

C

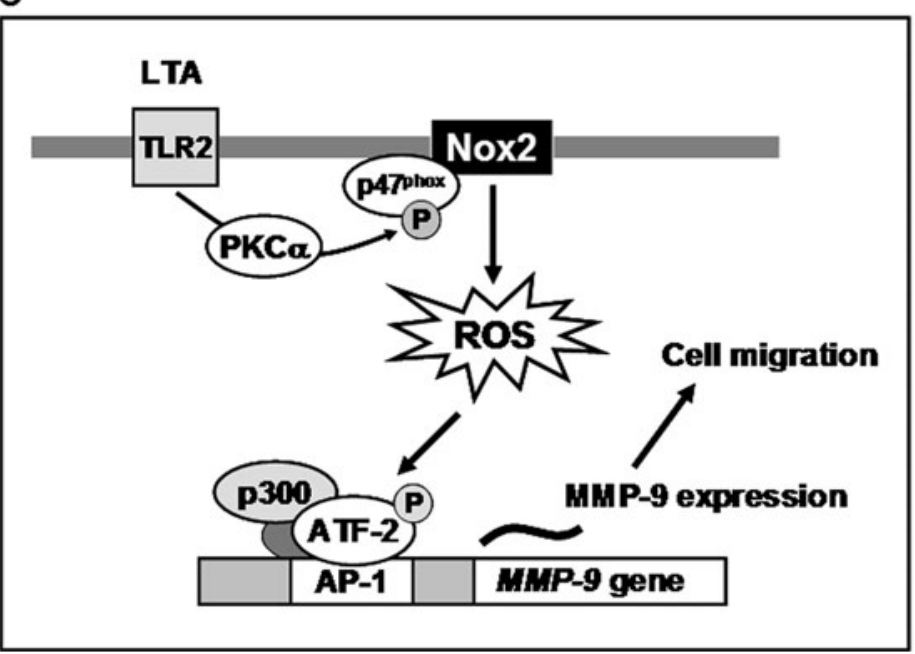

Figure 7 (See legend on next page.) 
(See figure on previous page.)

Figure 7 LTA enhances MMP-9 promoter activity and astrocytic migration. a Cells were transiently cotransfected with pGL-MMP9-LuC and pGal for 24 h, pretreated with Gö, DPI, Apo, NAC and GR343 for 1 h, and then incubated with LTA for $16 \mathrm{~h}$. The promoter activity was determined. $\mathbf{b}$ RBA-1 cells were plated on coverslips and grew to confluence; the coverslips were transferred to a new 10-cm dish containing serum-free medium for $24 \mathrm{~h}$. Cells were pretreated with MMP2/9i, Gö, DPI, NAC or GR343 for $1 \mathrm{~h}$, and then incubated with LTA (50 $\mu \mathrm{g} / \mathrm{ml})$ for 48 h. Phase contrast images of RBA-1 cells were taken. The number of LTA-induced cell migrations was counted. Data are expressed as the mean \pm SEM of three independent experiments. ${ }^{\#} P<0.01$, as compared with the cells stimulated with LTA alone. c Scheme of the LTA-mediated signaling pathways linked to MMP-9 expression and cell migration in brain astrocytes. Action of LTA to its receptors (TLR2) results in activation of PKCa/Nox2/ROS cascade. MMP-9 transcription is ATF-2/AP-1-dependently regulated by a ROS-dependent pathway. Moreover, p300 plays the role of an assistant mediator in these responses. This signaling pathway might contribute to sustained expression of MMP-9, which is required for cell migration in RBA-1 cells.

demonstrated that LTA-stimulated MMP-9 transcriptional activity via the same pathway by a wild-type rat MMP-9 promoter-luciferase reporter plasmid (pGLMMP-9-Luc) construct (Figure 7a). These results indicated that LTA-induced MMP-9 expression is mediated through a $\mathrm{PKC}(\alpha)$-dependent $\operatorname{Nox}(2) / \mathrm{ROS}$ signal, associated with activation of transcription factor ATF-2/AP-1 in RBA-1 cells. Consistently, in rat brain primary cultured astrocytes, we confirmed that LTA-induced MMP-9 expression may mediate through the same identified signaling (Figure 1d).

Cell motility is a fundamental process during embryonic development, wound healing, inflammatory responses and tumor metastasis [56]. It has been reported that MAPKs, NF-kB, AP-1 and MMP-9 $[17,18]$ contribute to cell motility in different cell types. In the study, we further demonstrated that in brain astrocytes, activation of a Nox-dependent ROS signal linking to ATF-2/AP-1 and p300, mediated through activation of PKC $\alpha$, is essential for LTA-induced MMP-9 gene expression and cell migration.

\section{Conclusions}

In summary, these results demonstrated that LTA induces MMP-9 expression via sequential activation of PKC $\alpha, \mathrm{p} 47^{\mathrm{phox}} / \mathrm{Nox} 2$, ROS, and transcription factor ATF2/AP-1 and co-activator p300, leading to the promotion of astrocytic migration. Although the molecular basis of the Nox-mediated redox signal in immune, cardiac and renal diseases is well established, the role of the Nox-mediated redox signal during acute or chronic brain inflammation is still unclear. We demonstrated that the Nox-mediated ROS signal may be a pivot molecule linking the PKC $\alpha$ and AP-1 signal; this leads to expression of MMP-9 in CNS infection. Pharmacological approaches suggest that targeting MMP-9 and its specific upstream signaling components should yield useful therapeutic targets for CNS inflammatory diseases upon infection with gram-positive bacteria.

\section{Competing interests}

The authors declare that they have no competing interests.

\section{Acknowledgements}

This work was supported by the National Science Council, Taiwan, grant nos. NSC99-2321-B182-003, NSC98-2320-B-182-004-MY3, NSC98-2320-B-255-001MY3; Chang Gung Medical Research Foundation, grant nos. CMRPD170493, CMRPD140253, CMRPD150253, CMRPD180372, CMRPF170023, CMRPF1A0061, CMRPG391031 and CMRPG381522; and the Ministry of Education, Taiwan, grant nos. EMRPD1B0311, EMRPD1B0321, EMRPD1A0831 and EMRPD1A0841. The authors also thank Ms. Yin-Chen Chen for her technical assistance with this article.

\section{Author details}

${ }^{1}$ Department of Nursing, Division of Basic Medical Sciences, Chang Gung University of Science and Technology, Tao-Yuan, Taiwan. ${ }^{2}$ Department of Anesthetics, Chang Gung Memorial Hospital and College of Medicine, Chang Gung University, Kwei-San, Tao-Yuan, Taiwan. ${ }^{3}$ Department of Pharmacology and Health Aging Research Center, College of Medicine, Chang Gung University, Tao-Yuan, Taiwan. ${ }^{4}$ Department of Pharmacology, College of Medicine, Chang Gung University, 259 Wen-Hwa 1st Road, Kwei-San, TaoYuan, Taiwan.

\section{Authors' contributions}

$\mathrm{CCL}, \mathrm{RHS}$ and LDH designed and performed experiments, acquisition and analysis of data, and drafted the manuscript. HLH and CMY co-conceived the study, participated in its design and coordination, were involved in drafting the manuscript and revising it critically for important intellectual content, and gave final approval of the version to be published. All authors read and approved the final version of this manuscript.

Received: 14 December 2011 Accepted: 29 May 2012

Published: 29 May 2012

\section{References}

1. Aoki T, Sumii T, Mori T, Wang X, Lo EH: Blood-brain barrier disruption and matrix metalloproteinase-9 expression during reperfusion injury: mechanical versus embolic focal ischemia in spontaneously hypertensive rats. Stroke 2002, 33:2711-2717.

2. Harris JE, Nuttall RK, Elkington PT, Green JA, Horncastle DE, Graeber MB, Edwards DR, Friedland JS: Monocyte-astrocyte networks regulate matrix metalloproteinase gene expression and secretion in central nervous system tuberculosis in vitro and in vivo. J Immunol 2007, 178:1199-1207.

3. Rosenberg GA: Matrix metalloproteinases in neuroinflammation. Glia 2002, 39:279-291.

4. Wu CY, Hsieh HL, Jou MJ, Yang CM: Involvement of p42/p44 MAPK, p38 MAPK, JNK and nuclear factor-KB in interleukin-1 $\beta$-induced matrix metalloproteinase-9 expression in rat brain astrocytes. J Neurochem 2004, 90:1477-1488.

5. Woo CH, Lim JH, Kim JH: Lipopolysaccharide induces matrix metalloproteinase- 9 expression via a mitochondrial reactive oxygen species-p38 kinase-activator protein-1 pathway in Raw 264.7 cells. $J$ Immunol 2004, 173:6973-6980.

6. Hsieh HL, Wang HH, Wu WB, Chu PJ, Yang CM: Transforming growth factor- $\beta 1$ induces matrix metalloproteinase- 9 and cell migration in astrocytes: roles of ROS-dependent ERK- and JNK-NF-KB pathways. J Neuroinflammation 2010, 7:88. 
7. Lee SJ, Lee S: Toll-like receptors and inflammation in the CNS. Curr Drug Targets Inflamm Allergy 2002, 1:181-191.

8. Konat GW, Kielian T, Marriott I: The role of Toll-like receptors in CNS response to microbial challenge. J Neurochem 2006, 99:1-12.

9. Kinsner A, Pilotto V, Deininger S, Brown GC, Coecke S, Hartung T, Bal-Price A: Inflammatory neurodegeneration induced by lipoteichoic acid from Staphylococcus aureus is mediated by glia activation, nitrosative and oxidative stress, and caspase activation. J Neurochem 2005,

95:1132-1143.

10. Lehnardt S, Henneke P, Lien E, Kasper DL, Volpe JJ, Bechmann I, Nitsch R, Weber JR, Golenbock DT, Vartanian T: A mechanism for neurodegeneration induced by group $B$ streptococci through activation of the TLR2/MyD88 pathway in microglia. J Immunol 2006, 177:583-592.

11. Neher JJ, Brown GC: Neurodegeneration in models of Gram-positive bacterial infections of the central nervous system. Biochem Soc Trans 2007, 35:1166-1167.

12. Carpentier PA, Duncan DS, Miller SD: Glial toll-like receptor signaling in central nervous system infection and autoimmunity. Brain Behav Immun 2008, 22:140-147.

13. Bowman CC, Rasley A, Tranguch SL, Marriott I: Cultured astrocytes express toll-like receptors for bacterial products. Glia 2003, 43:281-291.

14. Jack CS, Arbour N, Manusow J, Montgrain V, Blain M, McCrea E, Shapiro A, Antel JP: TLR signaling tailors innate immune responses in human microglia and astrocytes. J Immunol 2005, 175:4320-4330.

15. De Keyser J, Mostert JP, Koch MW: Dysfunctional astrocytes as key players in the pathogenesis of central nervous system disorders. J Neurol Sci 2008, 267:3-16.

16. Mullaly SC, Kubes P: The role of TLR2 in vivo following challenge with Staphylococcus aureus and prototypic ligands. J Immunol 2006, 177:8154-8163.

17. Hsieh HL, Wu CY, Yang CM: Bradykinin induces matrix metalloproteinase9 expression and cell migration through a PKC- $\delta$-dependent ERK/Elk-1 pathway in astrocytes. Glia 2008, 56:619-632.

18. Wang HH, Hsieh HL, Wu CY, Sun CC, Yang CM: Oxidized low-density lipoprotein induces matrix metalloproteinase- 9 expression via a p42/p44 and JNK-dependent AP-1 pathway in brain astrocytes. Glia 2009, 57:24-38.

19. O'Neill LA: Primer: Toll-like receptor signaling pathways-what do rheumatologists need to know? Nat Clin Pract Rheumatol 2008, 4:319-327.

20. Souza LF, Jardim FR, Sauter IP, Souza MM, Barreto F, Margis R, Bernard EA: Lipoteichoic acid from Staphylococcus aureus increases matrix metalloproteinase 9 expression in RAW 264.7 macrophages: modulation by A2A and A2B adenosine receptors. Mol Immunol 2009, 46:937-942.

21. Chrissobolis S, Faraci FM: The role of oxidative stress and NADPH oxidase in cerebrovascular disease. Trends Mol Med 2008, 14:495-502.

22. Valko M, Leibfritz D, Moncol J, Cronin MT, Mazur M, Telser J: Free radicals and antioxidants in normal physiological functions and human disease. Int J Biochem Cell Biol 2007, 39:44-84.

23. Demchenko IT, Oury TD, Crapo JD, Piantadosi CA: Regulation of the brain's vascular responses to oxygen. Circ Res 2002, 91:1031-1037.

24. Halliwell B: Oxidative stress and neurodegeneration: where are we now? J Neurochem 2006, 97:1634-1658.

25. Lewén A, Matz P, Chan PH: Free radical pathways in CNS injury. J Neurotrauma 2000, 17:871-890.

26. Lee IT, Wang SW, Lee CW, Chang CC, Lin CC, Luo SF, Yang CM: Lipoteichoic acid induces HO-1 expression via the TLR2/MyD88/c-Src/NADPH oxidase pathway and Nrf2 in human tracheal smooth muscle cells. J Immunol 2008, 181:5098-5110.

27. Chatterjee PK, Zacharowski K, Cuzzocrea S, Brown PA, Stewart KN, MotaFilipe H, Thiemermann C: Lipoteichoic acid from Staphylococcus aureus reduces renal ischemia/reperfusion injury. Kidney Int 2002, 62:1249-1263.

28. Jou TC, Jou MJ, Chen JY, Lee SY: Properties of rat brain astrocytes in longterm culture. J Formos Med Assoc 1985, 84:865-881.

29. Hsieh HL, Yen MH, Jou MJ, Yang CM: Intracellular signalings underlying bradykinin-induced matrix metalloproteinase- 9 expression in rat brain astrocyte-1. Cell Signal 2004, 16:1163-1176.

30. Reinehr R, Görg B, Becker S, Qvartskhava N, Bidmon HJ, Selbach O, Haas HL, Schliess F, Häussinger D: Hypoosmotic swelling and ammonia increase oxidative stress by NADPH oxidase in cultured astrocytes and vital brain slices. Glia 2007, 55:758-771.
31. LeBel CP, Ischiropoulos $H$, Bondy SC: Evaluation of the probe $2{ }^{\prime}, 7^{\prime}-$ dichlorofluorescein as an indicator of reactive oxygen species formation and oxidative stress. Chem Res Toxicol 1992, 5:227-231.

32. Parinandi NL, Kleinberg MA, Usatyuk PV, Cummings RJ, Pennathur A, Cardounel AJ, Zweier JL, Garcia JG, Natarajan V: Hyperoxia-induced NAD(P) $\mathrm{H}$ oxidase activation and regulation by MAP kinases in human lung endothelial cells. Am J Physiol Lung Cell Mol Physiol 2003, 284:L26-L38.

33. Nelson KK, Melendez JA: Mitochondrial redox control of matrix metalloproteinases. Free Radic Biol Med 2004, 37:768-784.

34. Infanger DW, Sharma RV, Davisson RL: NADPH oxidases of the brain: distribution, regulation, and function. Antioxid Redox Signal 2006, 8:15831596.

35. Bedard K, Krause KH: The NOX family of ROS-generating NADPH oxidases: physiology and pathophysiology. Physiol Rev 2007, 87:245-313

36. Fontayne A, Dang PM, Gougerot-Pocidalo MA, El-Benna J: Phosphorylation of $\mathrm{p} 47^{\text {phox }}$ sites by PKC $a, \beta I I, \delta$, and $\zeta$ : effect on binding to $\mathrm{p} 22^{\text {phox }}$ and on NADPH oxidase activation. Biochemistry 2002, 41:7743-7750.

37. Lin CW, Shen SC, Chien CC, Yang LY, Shia LT, Chen YC: 12-Otetradecanoylphorbol-13-acetate-induced invasion/migration of glioblastoma cells through activating PKCa/ERK/NF-KB-dependent MMP9 expression. J Cell Physiol 2010, 225:472-481.

38. Hsieh HL, Wang HH, Wu CY, Yang CM: Reactive Oxygen SpeciesDependent c-Fos/Activator Protein 1 Induction Upregulates Heme Oxygenase-1 Expression by Bradykinin in Brain Astrocytes. Antioxid Redox Signal 2010, 13:1829-1844

39. Chan HM, La Thangue NB: p300/CBP proteins: HATs for transcriptional bridges and scaffolds. J Cell Sci 2001, 114:2363-2373.

40. Svedin P, Hagberg H, Savman K, Zhu C, Mallard C: Matrix metalloproteinase-9 gene knock-out protects the immature brain after cerebral hypoxia-ischemia. J Neurosci 2007, 27:1511-1518.

41. McColl BW, Rothwell NJ, Allan SM: Systemic inflammation alters the kinetics of cerebrovascular tight junction disruption after experimental stroke in mice. J Neurosci 2008, 28:9451-9462.

42. Saez-Llorens $X$, McCracken GH Jr: Bacterial meningitis in children. Lancet 2003, 361:2139-2148.

43. Floyd RA: Neuroinflammatory processes are important in neurodegenerative diseases: an hypothesis to explain the increased formation of reactive oxygen and nitrogen species as major factors involved in neurodegenerative disease development. Free Radic Biol Med 1999, 26:1346-1355.

44. Qin L, Liu Y, Wang T, Wei SJ, Block ML, Wilson B, Liu B, Hong JS: NADPH oxidase mediates lipopolysaccharide-induced neurotoxicity and proinflammatory gene expression in activated microglia. $J$ Biol Chem 2004, 279:1415-1421.

45. Abramov AY, Jacobson J, Wientjes F, Hothersall J, Canevari L, Duchen MR: Expression and modulation of an NADPH oxidase in mammalian astrocytes. J Neurosci 2005, 25:9176-9184.

46. Liu Q, Kang JH, Zheng RL: NADPH oxidase produces reactive oxygen species and maintains survival of rat astrocytes. Cell Biochem Funct 2005 23:93-100.

47. Kim SY, Lee JG, Cho WS, Cho KH, Sakong J, Kim JR, Chin BR, Baek SH: Role of NADPH oxidase-2 in lipopolysaccharide-induced matrix metalloproteinase expression and cell migration. Immunol Cell Biol 2010, 88:197-204

48. Sen CK, Packer L: Antioxidant and redox regulation of gene transcription. FASEB J 1996, 10:709-720.

49. van Dam H, Castellazzi M: Distinct roles of Jun: Fos and Jun: ATF dimers in oncogenesis. Oncogene 2001, 20:2453-2464.

50. Kim ES, Sohn YW, Moon A: TGF- $\beta$-induced transcriptional activation of MMP-2 is mediated by activating transcription factor (ATF) 2 in human breast epithelial cells. Cancer Lett 2007, 252:147-156.

51. Aggeli IK, Gaitanaki C, Beis I: Involvement of JNKs and p38-MAPK/MSK1 pathways in $\mathrm{H} 2 \mathrm{O} 2$-induced upregulation of heme oxygenase-1 mRNA in H9c2 cells. Cell Signal 2006, 18:1801-1812.

52. Wu CY, Hsieh HL, Sun CC, Tseng CP, Yang CM: IL-1 $1 \beta$ induces proMMP-9 expression via c-Src-dependent PDGFR/PI3K/Akt/p300 cascade in rat brain astrocytes. J Neurochem 2008, 105:1499-1512.

53. Cheng SE, Lin CC, Lee IT, Hsu CK, Kou YR, Yang CM: Cigarette smoke extract regulates cytosolic phospholipase A2 expression via NADPH oxidase/MAPKs/AP-1 and p300 in human tracheal smooth muscle cells. J Cell Biochem 2011, 112:589-599. 
54. Lauffenburger DA, Horwitz AF: Cell migration: a physically integrated molecular process. Cell 1996, 84:359-369.

55. Hsieh HL, Wang HH, Wu CY, Tung WH, Yang CM: Lipoteichoic acid induces matrix metalloproteinase-9 expression via transactivation of PDGF receptors and NF-KB activation in rat brain astrocytes. Neurotox Res 2010, 17:344-359.

56. Wang HH, Hsieh $\mathrm{HL}$, Yang CM: Calmodulin kinase II-dependent transactivation of PDGF receptors mediates astrocytic MMP-9 expression and cell motility induced by lipoteichoic acid. J Neuroinflammation 2010, $7: 84$.

doi:10.1186/1742-2094-9-110

Cite this article as: Hsieh et al: NADPH oxidase-mediated redox signal contributes to lipoteichoic acid-induced MMP-9 upregulation in brain astrocytes. Journal of Neuroinflammation 2012 9:110.

\section{Submit your next manuscript to BioMed Central and take full advantage of:}

- Convenient online submission

- Thorough peer review

- No space constraints or color figure charges

- Immediate publication on acceptance

- Inclusion in PubMed, CAS, Scopus and Google Scholar

- Research which is freely available for redistribution 